\title{
RADON IN GROUNDWATERS IN THE BAIKAL REGION AND TRANSBAIKALIA: VARIATIONS IN SPACE AND TIME
}

\author{
K. Zh. Seminsky ${ }^{1,2}$, A. K. Seminsky ${ }^{1}$ \\ ${ }^{1}$ Institute of the Earth's crust, Siberian Branch of RAS, Irkutsk, Russia \\ ${ }^{2}$ Irkutsk Scientific Center, Siberian Branch of RAS, Irkutsk, Russia
}

\begin{abstract}
This study aimed to provide a systematic overview of water sources in the Baikal region and Transbaikalia by the content of radon (Q) and establish regularities in variations of $Q$ values in space and time.

We collected and analyzed our evaluations of $Q$ and the available published $Q$ values for many dozens of water sources in the study area (Fig. 1), and reviewed the monitoring data of eight water sources that belong to the Angarsky fault impact zone in Southern Priangarie (Fig. 5). Radon content in water samples was measured in accordance with the standard procedure using a RRA-01M-03 radiometer (sensitivity of at least $1.4 \cdot 10^{-4} \mathrm{~s}^{-1} \cdot \mathrm{Bq}^{-1} \cdot \mathrm{m}^{3} ;$ maximum allowable relative error of $30 \%$ ).

Based on the frequency patterns of Q values measured in the Baikal region and Transbaikalia (Fig. 2) and the analysis of the known classifications of the water sources by radioactivity, we propose a uniform regional classification of groundwaters with respect to ${ }^{222} \mathrm{Rn}$ content (Table 1). In seismically active Baikal region, wherein water sources with $\mathrm{Q}>185 \mathrm{~Bq} / \mathrm{l}$ are practically lacking, we distinguish the first three groups with the following $\mathrm{Q}$ ranges: Group I $-\mathrm{Q} \leq 15$ $\mathrm{Bq} / \mathrm{l}$, Group II $-16 \leq \mathrm{Q} \leq 99 \mathrm{~Bq} / \mathrm{l}$, and Group III $-100 \leq \mathrm{Q} \leq 184 \mathrm{~Bq} / \mathrm{l}$. Most of the water sources sampled in the Baikal region and Transbaikalia belong to Groups I and II, which allows us to recommend an objectively existing value of $100 \mathrm{~Bq} / \mathrm{l}$ as the level of intervention in the preparation of drinking water in this region, instead of the limit of $60 \mathrm{~Bq} / \mathrm{l}$ that is now approved in Russia.

In order to identify the special patterns of groundwater sources in the Baikal region and Transbaikalia, which belong to different radioactivity groups, we sampled these sources along the transect from Bayanday to Muhorshibir, across the Baikal rift and other large regional tectonic structures (Fig. 4). On a larger scale, we analysed the radon content variability in the groundwater sources within the zones influenced by the Tunka normal fault (Fig. 3), Primorsky normal fault, Angarsky strike-slip fault with a normal component, and other active faults located in the study region.
\end{abstract}

Within the framework of the spatial aspect, the material and structural factors determining the radioactivity of groundwaters in the study region are identified. Our data support the results of the previous studies showing a generally lower radon content in groundwaters in the Baikal region in comparison with those in Transbaikalia that is characterized by a higher radioactivity due to the abundant granitoids of different types. The background concentrations of the radioactive gas in the Baikal region correspond to Group I, and in those in Transbaikalia to Group II. The boundary between the regions with different levels of radioactivity of groundwaters is shifted southeastward from the central structures of the Baikal rift. Within the Bayanday-Muhorshibir transect, it coincides with the known boundary between the Transbaikalia province of cold carbonic acid waters and the Baikal province of nitrogen and methan terms (see Fig. 4). The structural factor of formation of the emanation field refers to an increase in radioactivity of water associated with the faults, whereat an increased permeability and higher geodynamic activity cause a more intensive radon emanation and/or the occurrence of emanating reservoirs (see Fig. 3, and 4). In the Baikal region, water sources of Group II are generally associated with faults, while in Transbaikalia, groundwater sources belonging to groups III and VI are typically related to faults.

To clarify the pattern of temporal variations in groundwater radioactivity, we analysed long rows of the monitored Q values (9 to 30 months) in eight water sources in the Angarsky fault zone in Southern Priangarie (see Fig. 5 , and 6). According to the adopted classification (see Table 1), three water sources belong to the near-surface sources (Group I), and there are five deeper near-fault water sources (Group II). Despite the distinct variations in radioactivity, the $Q$ values recorded through most of the monitoring time do not exceed the threshold $Q$ values for the respective groups. It appears that the observed periodic anomalously high and low contents of radon are due to seasonally variable meteorological parameters (see Fig. 6).

The correlation analysis of $Q$ values and atmospheric pressure (P), air humidity $(\mathrm{U})$ and temperature $(\mathrm{T})$ shows a clear dependence of the content of radon in groundwater on $\mathrm{T}$ and $\mathrm{P}$ values (Table 3). Following the major seasonal trend of air temperature, the level of radioactivity is increased in the water samples taken in winter and decreased in 
summer (see Fig. 6). Q values are indirectly influenced by parameter $\mathrm{T}$ via changes of water temperature, variations in flow rates of water sources, freezing of the top layer of soil and other processes, which parameters require further research.

According to the monitoring data (see Table 3, and Fig. 6, A), the content of radon in near-surface water sources (Group I) can vary by a few and the first dozens of units, while changes by tens of becquerel per liter are recorded in the deeper near-fault water sources (Group II). As a consequence, in short periods of extreme Q values, the content of radon in a water source may increase or decrease to a value corresponding to a neighbouring radon-radioactivity group.

This paper provides an overview of the radon activity of groundwater in the Baikal region and Transbaikalia with a focus on regularities in the spatial and temporal patterns of ${ }^{222} \mathrm{Rn}$ in the water sources with $\mathrm{Q}<185 \mathrm{~Bq} / \mathrm{l}$. The nonradon waters are more abundant in the Baikal region, including areas of active use of natural resources. Although the content of ${ }^{222} \mathrm{Rn}$ in low, such waters should be a target of further research aimed to explore medicinal water sources, assess drinking water quality, and discover the emanation precursors of strong earthquakes in the study region.

Key words: radon; groundwater; fault; monitoring; meteorological factors

Recommended by V.V. Ruzhich

For citation: Seminsky K.Zh., Seminsky A.K. 2016. Radon in groundwaters in the Baikal region and Transbaikalia: variations in space and time. Geodynamics \& Tectonophysics 7 (3), 477-493. doi:10.5800/GT2016-7-3-0218.

Для цитирования: Семинский К.Ж., Семинский А.К. Радон в подземных водах Прибайкалья и Забайкалья: пространственно-временные вариации // Геодинамика и тектонофизика. 2016. Т. 7. № 3. C. 477-493. doi:10.5800/GT-2016-7-3-0218.

\title{
РАДОН В ПОДЗЕМНЫХ ВОДАХ ПРИБАЙКАЛЬЯ И ЗАБАЙКАЛЬЯ: ПРОСТРАНСТВЕННО-ВРЕМЕННЫЕ ВАРИАЦИИ
}

\author{
К. Ж. Семинский ${ }^{1,2}$, А.К. Семинский 1 \\ ${ }^{1}$ Институт земной коры СО РАН, Иркутск, Россия \\ ${ }^{2}$ Иркутский научный центр СО РАН, Иркутск, Россия
}

Аннотация: Целью исследований было провести систематизирование водопроявлений Прибайкалья и Забайкалья по содержанию радона $(Q)$, а также установить закономерности изменчивости параметра $Q$ в пространстве и времени.

Фактическим материалом для анализа послужили собственные и заимствованные из литературных источников оценки параметра $Q$ во многих десятках водопроявлений региона (рис. 1), а также данные мониторинга восьми источников, принадлежащих к зоне влияния Ангарского разлома в Южном Приангарье (рис. 5). Измерения содержания радона в пробах воды проводились в соответствии со стандартной методикой при помощи радиометра PPA-01M-03, который характеризуется чувствительностью не менее $1.4 \cdot 10^{-4} \mathrm{c}^{-1} \cdot \mathrm{Б}^{-1} \cdot \mathrm{M}^{3}$ и 30\%-ным пределом допустимой относительной погрешности.

Частотное распределение величин $Q$, измеренных в Прибайкалье и Забайкалье (рис. 2), а также анализ известных классификаций водопроявлений по радиоактивности позволили предложить единую для изученного региона систематику подземных вод в зависимости от содержания ${ }^{22} 2 \mathrm{Rn}$ (табл. 1). Для сейсмически активного Прибайкалья, где источники собственно радоновых вод с $Q>185$ Бк/л почти не встречаются, практическое значение имеет выделение трех первых групп со следующими пределами изменения параметра $Q$ : группа I - Q $\leq 15$ Бк/л, группа II - $16 \leq Q \leq 99$ Бк/л, группа III - $100 \leq Q \leq 184$ Бк/л. Большинство опробованных в Прибайкалье и Забайкалье источников относится к группам I и II, что позволяет рекомендовать объективно существующую величину 100 Бк/л в качестве уровня вмешательства при подготовке питьевой воды в регионе вместо предела в 60 Бк/кг, принятого сейчас в России.

Для выявления пространственных закономерностей распространения в Прибайкалье и Забайкалье источников подземных вод, относящихся к разным группам по радиоактивности, проведено их опробование вдоль трансекта Баяндай-Мухоршибирь, пересекающего Байкальский рифт и другие крупные тектонические структуры изучаемого региона (рис. 4). В более крупном масштабе выполнен анализ изменчивости содержания радона в источниках подземных вод, приуроченных к отдельным участкам зон влияния Тункинского сброса (рис. 3), Приморского сброса, Ангарского сбросо-сдвига и других активных разломов изучаемого региона. 
В рамках пространственного аспекта проведенного исследования выделены вещественный и структурный факторы, определяющие радиоактивность подземных вод рассматриваемого региона. Подтверждены результаты предшествовавших исследований, свидетельствующие в целом о меньшем содержании радона в подземных водах Прибайкалья в сравнении с Забайкальем, где повышенная радиоактивность обусловлена широким распространением разнотипных гранитоидов. Фоновые концентрации радиоактивного газа в Прибайкалье соответствуют группе I, а в Забайкалье - группе II. Граница между областями с разной радиоактивностью подземных вод смещена к юго-востоку от приосевых структур Байкальского рифта. В пределах трансекта Баяндай - Мухоршибирь она совпадает с известной границей между Забайкальской провинцией холодных углекислых вод и Байкальской провинцией азотных и метановых терм (рис. 4). Структурный фактор формирования эманационного поля выражается в повышении радиоактивности вод, приуроченных к разломам, где вследствие повышенной проницаемости и геодинамической активности интенсифицируется выход радона и/или создаются эманирующие коллекторы (рис. 3, 4). В Прибайкалье с разломами обычно связаны водопроявления группы II, а в Забайкалье - источники подземных вод, принадлежащие к группам III-VI.

Для выявления характера временных вариаций радиоактивности подземных вод были проанализированы длинные ряды (от 9 до 30 месяцев) мониторинга значений $Q$ в восьми водопроявлениях из зоны Ангарского разлома в Южном Приангарье (рис. 5, 6). Согласно принятой классификации (табл. 1), три водопункта относились к близповерхностным источникам (группа I) и пять водопроявлений - к источникам более глубоких разломных вод (группа II). Несмотря на отчетливые вариации радиоактивности, большую часть времени мониторинга изученные водопроявления не выходили за пороговые значения $Q$ в пределах соответствующих групп. Периодические появления аномально высоких и низких содержаний радона оказались связанными с сезонными вариациями метеопараметров (рис. 6).

Корреляционный анализ величины $Q$ с атмосферным давлением (P), влажностью (U) и температурой (T) воздуха показал существование отчетливой зависимости содержания радона в подземных водах от величин Т и P (табл. 3). Вслед за ведущим сезонным трендом температуры воздуха радиоактивность исследуемых вод увеличивается зимой и уменьшается летом (рис. 6). Параметр Т оказывает опосредованное влияние на величину $Q$ через изменение температуры воды, вариации дебита водоисточников, промерзание верхнего слоя грунтов и другие процессы, параметрическое изучение которых представляет задачу дальнейших исследований по проблеме.

Согласно данным мониторинга (табл. 3 , рис. $6, A$ ), содержание радона у близповерхностных водопроявлений из группы I может меняться на единицы и первые десятки, а для более глубоких (приразломных) водоисточников группы II - на десятки беккерелей на литр. Как следствие, в непродолжительные периоды проявления экстремальных значений $Q$ содержание радона в воде конкретного источника может повыситься или понизиться до значений, соответствующих смежной группе по радиоактивности.

В работе охарактеризована радоновая активность подземных вод Прибайкалья и Забайкалья, причем особый акцент сделан на закономерностях пространственной и временной изменчивости содержания ${ }^{222} \mathrm{Rn}$ в водопроявлениях с $Q<185$ Бк/л. Это нерадоновые воды, которые наиболее распространены в Прибайкалье, включая районы активного природопользования. Несмотря на низкое содержание ${ }^{222} \mathrm{Rn}$, они являются важным объектом дальнейших целенаправленных исследований по поиску лечебных вод, оценке качества питьевой воды и выявлению эманационных предвестников сильных землетрясений в регионе.

Ключевые слова: радон; подземные воды; разлом; мониторинг; метеофакторы

\section{1. ВВЕДЕНИЕ}

Регион исследований, в пределах которого находится оз. Байкал, относится к территориям активного природопользования и характеризуется высокой сейсмичностью, связанной с процессом рифтообразования у южного края Сибирской платформы (рис. 1). Изучение радона (222Rn) в подземных водах данной территории имеет особое значение, так как его содержание $(Q$, Бк/л) является индикатором важных экологических функций литосферы [Trofimov, 2000]. Высокие концентрации ${ }^{222} \mathrm{Rn}$ представляют один из главных факторов онкологических заболеваний, отражают активные перемещения по разломам (в т.ч. происходящие при подготовке сильных землетрясений), свидетельствуют о местах локализации урановых руд.
Предшествовавшие исследования в Прибайкалье и Забайкалье [Mineral waters..., 1962; Myasnikov et al., 2009; Chernyago et al., 2012; и др.] были направлены главным образом на поиски подземных вод с $Q \geq 185$ Бк/л, т.е. по существующей классификации принадлежащих к собственно радоновым [Kulikov et al., 1991]. На современном этапе более углубленных исследований особое значение приобретает изучение водопроявлений, в которых содержание радиоактивного газа меньше указанного уровня. В пределах тектонически активной территории Прибайкалья именно такие воды преобладают по распространенности. Их исследование, кроме изучения фундаментальных проблем гидрогеохимии, необходимо для решения целой серии практических задач, актуальных для рассматриваемого региона. 


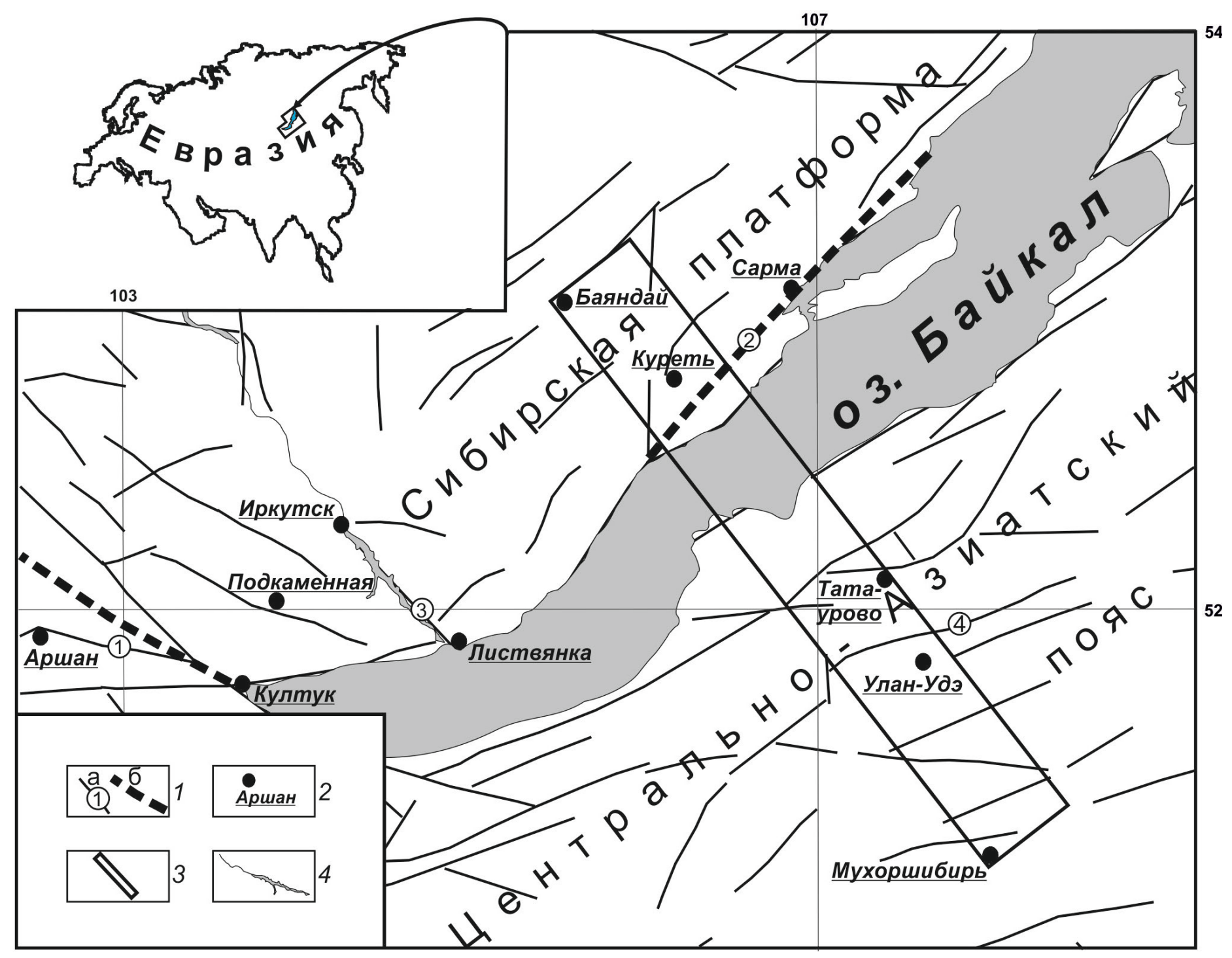

Рис. 1. Расположение участков опробования подземных вод на схеме разломов Прибайкалья и Западного Забайкалья.

1 - разломы (а) и краевой шов платформы (б); 2 - участки сосредоточения точек опробования подземных вод в окрестностях населенных пунктов; 3 - контур, в пределах которого располагаются пять участков опробования и отдельные пункты изучения подземных вод, составляющие трансект Баяндай - Мухоршибирь; 4 - гидросеть.

Fig. 1. Schematic map of faults in the Baikal region and Western Transbaikalia showing locations of groundwater sampling sites.

1 - faults (a) and the platform's marginal suture (б); 2 - groundwater sampling sites in the vicinity of settlements; 3 - contour of the area with five sampling sites and individual groundwater monitoring stations that comprise the Bayanday - Muhorshibir transect; 4 - hydrographic network.

К таким задачам относятся вопросы питьевого водоснабжения, поскольку принятый в России (согласно НРБ-99/2009) уровень вмешательства по содержанию радона составляет величину 60 Бк/кг, т.е. примерно в три раза меньше концентрации

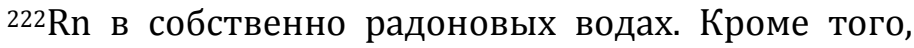
для туристско-рекреационной зоны Южного Прибайкалья актуальна проблема поиска лечебных вод, успешное решение которой позволит органи- зовать санатории и базы отдыха, используя для этого инфраструктуру, сохранившуюся после закрытия вредных производств (например, целлюлозно-бумажный комбинат в г. Байкальске). Еще одна прикладная задача состоит в определении водопроявлений, пригодных для мониторинга радона и использования его данных для выявления в Прибайкалье эманационных предвестников землетрясений по примеру других сейсмоактивных рай- 
онов [Toutain, Baubron, 1999; Ghosh et al., 2009; Woith, 2015].

Решение перечисленных задач должно базироваться на общей характеристике радиоактивности подземных вод региона, обусловленной содержанием в них растворенного радона. В связи с этим главными задачами представленного исследования было, во-первых, разделить подземные воды Прибайкалья и Забайкалья на группы в зависимости от содержания радона, во-вторых, установить закономерности их пространственного распространения и, в-третьих, выявить наиболее общие особенности временной изменчивости концентрации ${ }^{222} \mathrm{Rn}$ в подземных водах изучаемого региона.

\section{2. РЕЗУЛЬТАТЫ ИССЛЕДОВАНИЙ И ОБСУЖДЕНИЕ}

Фактическим материалом для исследования были измерения содержания радона в нескольких десятках слабоминерализованных водопроявлений Прибайкалья и Забайкалья, приуроченных к зонам активного и затрудненного водообмена. Измерения проводились в соответствии со стандартной методикой [Express method..., 2004] при помощи радиометра PРA-01M-03, который характеризуется чувствительностью не менее $1.4 \cdot 10^{-4} \mathrm{c}^{-1} \cdot \mathrm{Б \kappa}^{-1 \cdot \mathrm{M}^{3}}$ и 30\%-ным пределом допустимой относительной погрешности. Пункты измерений были сосредоточены на двенадцати участках, пять из которых располагались в пределах трансекта Баяндай - Мухоршибирь, пересекающего изучаемый регион вкрест простирания главных тектонических структур, в т.ч. Байкальского рифта (рис. 1). Массив значений параметра $Q$, проанализированный в ходе исследований, получен в результате единичных и мониторинговых измерений, особенности которых будут представлены в каждом из основных разделов данной статьи.

\section{1. КЛАССИФИКАЦИЯ ИСТОЧНИКОВ ПОДЗЕМНЫХ ВОД ПРИБАЙКАЛЬЯ И ЗАБАЙКАЛЬЯ ПО СОДЕРЖАНИЮ РАДОНА}

Для решения первой из поставленных задач было опробовано более 140 водопунктов (родники, скважины, колодцы). Кроме того, в базу анализируемых данных были включены сведения о 128 гидрогеологических объектах из каталога минеральных вод юга Восточной Сибири [Mineral waters..., 1962], треть которых является радоновыми. Удовлетворительная сходимость оценок, сделанных нами и предшественниками для одних и тех же водопроявлений, позволила рассматривать две совокупности данных в рамках единой выборки.
В ходе анализа массива количественных данных установлено существование значительного интервала величин $Q$ (152-180 Бк/л), не представленного водопроявлениями, что свидетельствует об актуальности для рассматриваемой территории порогового значения 185 Бк/л, отделяющего радоновые воды от нерадоновых [Kulikov et al., 1991]. Для удобства дальнейшего анализа на рис. 2 представлена гистограмма значений $Q$, соответствующих только тем водопроявлениям, которые не относятся к собственно радоновым. В области значений изучаемого параметра $0<Q \leq 185$ Бк/л график характеризуется существованием трех отчетливо выраженных минимумов. Они позволяют разделить нерадоновые воды на группы с минимальным (I группа: $Q \leq 15$ Бк/л), средним (II группа: $16 \leq Q \leq 99$ Бк/л) и повышенным (III группа: $100 \leq Q \leq 184$ Бк/л) содержанием радиоактивного газа.

К первой группе относится $41.5 \%$, ко второй $43.8 \%$ и к третьей - $14.7 \%$ опробованных источников. Содержание радона в половине водопроявлений из группы I составило не более 4 Бк/л, что свидетельствует об отсутствии взаимосвязи приповерхностных вод с глубинными. В большинстве опробованных источников концентрация радона не превысила 100 Бк/л (группы I и II). Следовательно, этот предел представляется более объективным в качестве уровня вмешательства для подготовки питьевой воды в Прибайкалье и Забайкалье по сравнению с действующим сейчас в России (60 Бк/кг по ГОСТ Р 51232-98) или ПДК по радону, применявшейся ранее (120 Бк/л).

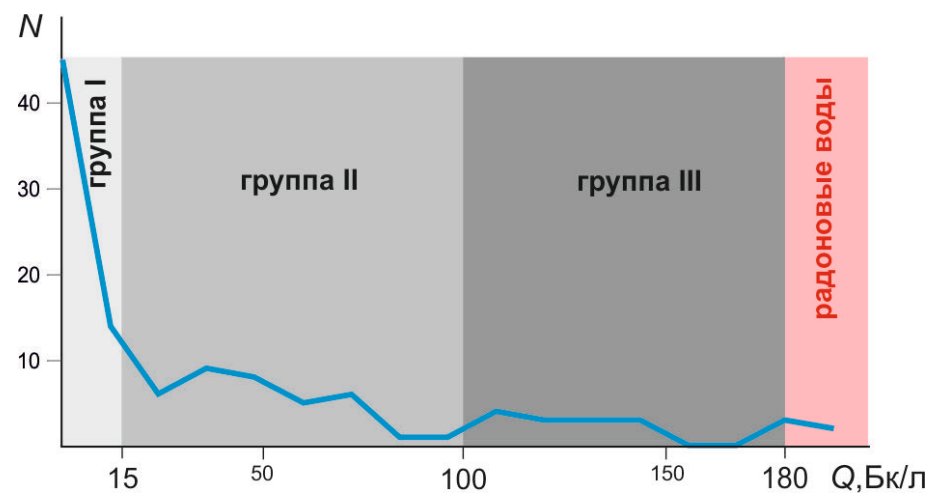

Рис. 2. Гистограмма распределения содержаний радона $(Q)$ в водопроявлениях Прибайкалья и Забайкалья, позволяющая разделить источники подземных вод с $Q<185$ Бк/л на три группы (N - частота встречаемости значений $Q$ ).

Fig. 2. Histogram of the distribution of radon contents $(Q)$ in water sources in the Baikal region and Transbaikalia. Based on it, the groundwater sources with $Q<185 \mathrm{~Bq} / \mathrm{l}$ are classified into three groups ( $\mathrm{N}$ - frequency of $Q$ values). 
Следует отметить, что подавляющее большинство известных систематик водопроявлений, бази-

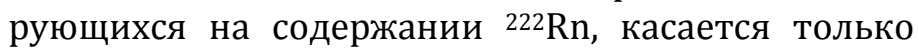
радоновых вод. В России выделяют очень слаборадоновые (185-750 Бк/л), слаборадоновые (7501500 Бк/л), радоновые средней концентрации (1500-7500 Бк/л) и высокорадоновые (более 7500 Бк/л) воды [Kulikov et al., 1991]. Т.А. Прзялибский [Przylibski, 2011] изучил полный спектр вариаций параметра $Q$, который составил шесть порядков, что позволило разделить все водопроявления на шесть групп: 1 - <1 Бк/дм³ 22 - 1-9.9(9) Бк/дм³ 3 10-99.9(9) Бк/дм³ 4 - 100-999.9(9) Бк/дм³ 5 1000-9999.9(9) Бк/дм³; 6 - $\geq 10000$ Бк/дм³.

Уровни содержания радона, определенные нами для Прибайкалья и Забайкалья (15 и 100 Бк/л), близки или совпадают с нижними границами, выделенными в [Przylibski, 2011] для группы 3 $\left(10\right.$ Бк/дм $\left.{ }^{3}\right)$ и группы 4 (100 Бк/дм³). Это свидетельствует об объективности существования этих и, вероятно, других обсуждаемых здесь уровней содержания радона в естественных водопроявлениях.

Классификация, предложенная Т.А. Прзялибским [Przylibski, 2011], привлекает своей строгой формализацией (различие уровней на порядок) и в этом отношении может быть базовой для обобщенных условий миграции подземных вод в верхней части подземной гидросферы. Однако для практических исследований большей значимостью обладают уровни, непосредственно определенные для конкретного региона. Таким образом, учитывая результаты исследований, представленные в данном разделе, в классификацию подземных вод Прибайкалья и Забайкалья по содержанию радона следует включить семь групп (табл. 1).

\section{2. ЗАКОНОМЕРНОСТИ ПРОСТРАНСТВЕННОГО РАСПРЕДЕЛЕНИЯ ПОДЗЕМНЫХ ВОД, ОТЛИЧАЮЩИХСЯ ПО СОДЕРЖАНИЮ РАДОНА, В ПРИБАЙКАЛЬЕ И ЗАБАЙКАЛЬЕ}

Как известно, содержание радона в подземных водах определяется радиоактивностью пород, сла- гающих верхнюю часть земной коры, а также ее нарушенностью разломами, которые являются путями миграции флюидов и газов. В связи с этим, чтобы в рамках решения второй задачи исследования охарактеризовать наибольшее количество структурно-вещественных обстановок в Прибайкалье и Забайкалье, были проанализированы данные опробования для отдельных водопроявлений или совокупностей участков, располагающихся преимущественно вкрест простирания разломов и более протяженных тектонических структур рассматриваемого региона (см. рис. 1). В крупном масштабе исследований такими объектами были серии водопроявлений, которые располагались на локальных участках вкрест простирания отдельных дизъюнктивов: Тункинский сброс на участке «Аршан», Приморский сброс на участке «Куреть», Ангарский сбросо-сдвиг на участке «Иркутск» и др. Исследования в мелком масштабе концентрировались на трансекте Баяндай - Мухоршибирь, пересекающем Байкальский рифт и другие крупные структуры изучаемого региона.

Результаты крупномасштабных исследований иллюстрирует рис. 3 , который на примере Тункинского сброса (участок «Аршан») отражает закономерности пространственного распределения водопроявлений с различным содержанием радона, располагающихся на изученных участках вблизи разломов. Пять опробованных источников образуют поперечный профиль, протягивающийся от выраженного уступом главного сместителя в лежачее крыло на 1.5 км (рис. 3, Б). Измерения проводились пять раз в течение двухмесячного промежутка времени (06.10.2012 г. - 15.12.2012 г.) с интервалом между опробованиями 2-3 недели.

Как видно из полученных графиков (рис. 3,5 ), области сместителя во всех случаях соответствуют наиболее высокие концентрации радона в подземных водах, источники которых по предложенной классификации относятся к группе II (пункты опробования 1241 и 1242). По мере удаления в крыло дизъюнктива радиоактивность подземных

T а б л и ц а 1 . Классификация грунтовых вод Прибайкалья и Забайкалья по содержанию $222 \mathrm{Rn}$

$\mathrm{T}$ a b l e 1. Classification of groundwaters in the Baikal rigion and Transbaikalia by ${ }^{222} \mathrm{Rn}$ content

\begin{tabular}{lll}
\hline & Группы грунтовых вод & Q, Бк/л \\
\hline 1 & I & $\leq 15$ \\
2 & II & $16-99$ \\
3 & III & $100-184$ \\
4 & IV (очень слаборадоновые) & $185-750$ \\
5 & V (слаборадоновые) & $750-1500$ \\
6 & VI (радоновые средней концентрации) & $1500-7500$ \\
7 & VII (высокорадоновые) & $>7500$ \\
\hline
\end{tabular}



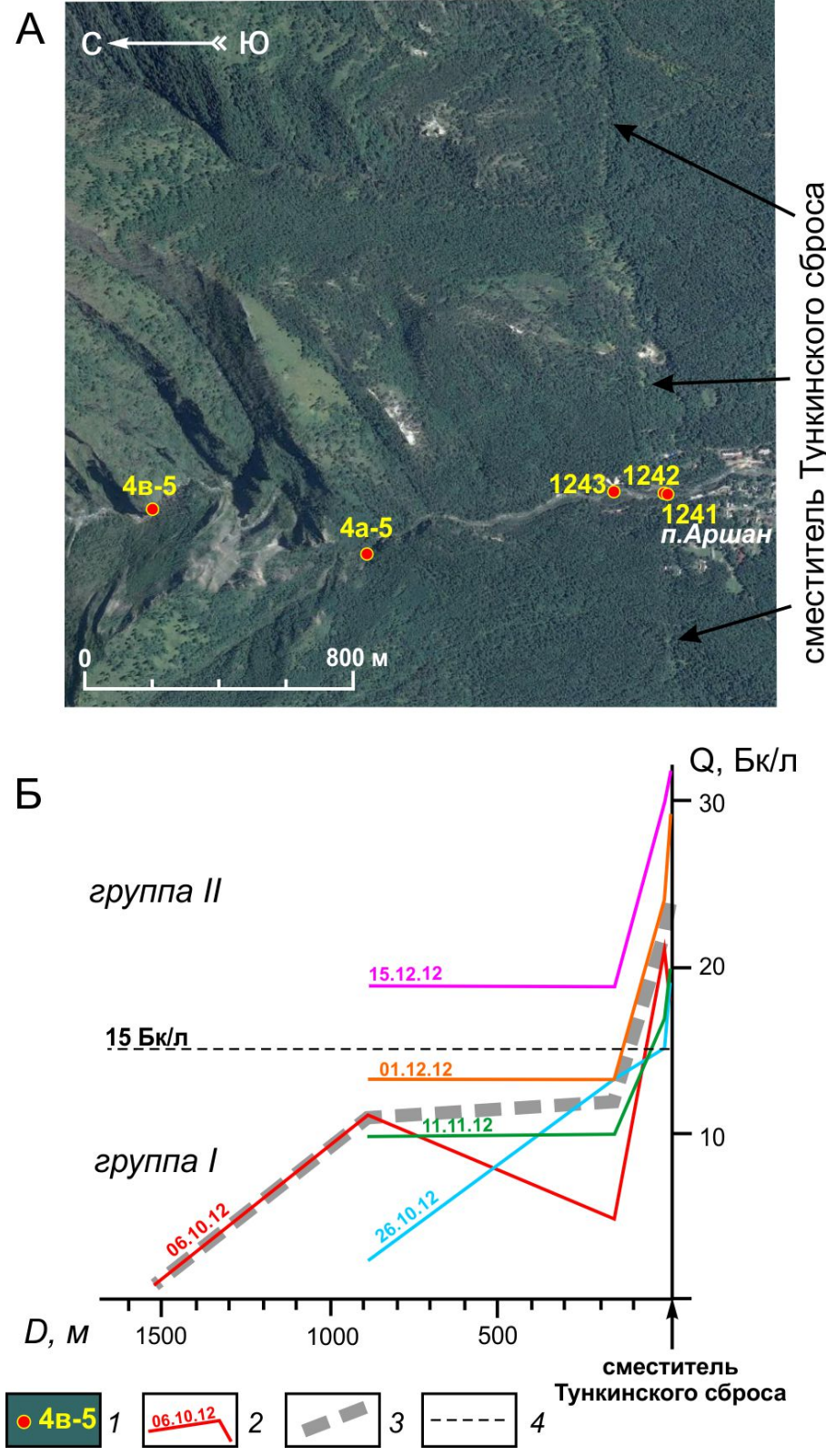

вод уменьшается до минимальных значений $Q$, соответствующих практически для всех моментов опробования группе I (пункты 4a-5 и 4в-5). Падение концентрации радона происходит неравномерно, а при измерениях 6 октября - даже с существованием минимумов (пункты 1241 и 1243), нарушающих общий тренд изменения величины $Q_{c p}$ (пунктир серого цвета).

Вариации подобного типа не могут быть связаны с различием радиоактивности пород участка исследований, а скорее свидетельствуют об особенностях динамики подземных вод, проявляющейся в породах с разной проницаемостью. В интенсивно нарушенных разломных зонах она наибольшая и может варьироваться вследствие неоднородности разрывной структуры, а также неравномерности степени современной активности
Рис. 3. Вариации содержания радона $(Q)$ в источниках подземных вод, располагающихся в лежачем крыле Тункинского сброса (окрестности пос. Аршан, Республика Бурятия).

$A$ - положение сместителя Тункинского сброса и пунктов опробования подземных вод на космоснимке. 5 - графики, отражающие изменение радиоактивности подземных вод в разные моменты времени в зависимости от расстояния до главного разломного сместителя $(D) .1$ - положение водопроявления и его индекс; 2 - график, соответствующий одному времени измерений (у каждой кривой показана дата опробования); 3 - график, построенный по средним значениям $Q$ за весь период измерений; 4 - уровень, разделяющий на графике величины параметра $Q$, соответствующие подземным водам из двух разных групп по содержанию радона.

Fig. 3. Radon content $(Q)$ variations in groundwater sources located in the lying wing of the Tunka normal fault (near the Arshan village, The Republic of Buryatia).

$A$ - position of the main plane of the Tunka normal fault and locations of groundwater sampling points (satellite image). 5 plots showing changes (at different times) in groundwater radioactivity depending on the distance to the main fault plane $(D)$. 1 - water source position and index; 2 - plot corresponding to the same time of measurements (sampling dates are shown at each curve); 3 - plot based on mean $Q$ values for the entire measurement period; 4 - line separating $Q$ values corresponding to groundwaters from two groups that differ in the radon content.

подвижек по отдельным сместителям. Как следствие, маркирование магистральных разломов водопроявлениями с относительно высоким содержанием радона и неравномерное уменьшение радиоактивности подземных вод в направлении крыльев характерны для различных регионов [Steinitz et al., 1992; Guerra, Etiope, 1999]. В Прибайкалье и Забайкалье поперечные профили аналогичного типа выявлены у приразломных аномалий почвенного радона [Koval et al., 2006; Plyusnin et al., 2009; Chernyago et al., 2012; Seminsky, Bobrov, 2012; Seminsky et al., 2013]. Радиоактивность подземных вод с рассматриваемых здесь позиций целенаправленно не изучалась, хотя предшественниками отмечалось, что в Забайкалье выходы радоновых вод связаны с эманирующими коллекторами, которые приурочены к крупным разломным 
сместителям [Mineral waters..., 1962; Plyusnin et al., 2009].

Результаты мелкомасштабных исследований пространственного распределения водопроявлений, относящихся к разным группам по содержанию радона, иллюстрируются на примере трехсоткилометрового трансекта (см. рис. 1), представленного цепочкой из пяти участков опробования подземных вод («Баяндай», «Куреть», «Татаурово», «Удан-Удэ», «Мухоршибирь»). На рис. 4 для трансекта показана принадлежность отдельных водопроявлений к группам с разным содержанием ${ }^{222 \mathrm{Rn}}$ (рис. $4, A$ ), положение разломов, впадин и поднятий на графике высотных отметок рельефа (рис. $4, B$ ), а также вариации концентрации радона в почве по данным предшествовавших исследований (рис. 4, Б). Анализ полученных материалов подтверждает известный вывод [Myasnikov et al., 2009] о меньшей в целом концентрации ${ }^{222} \mathrm{Rn}$ в водах и почвах Прибайкалья по сравнению с Забайкальем - областью распространения гранитоидов, которые, как правило, отличаются повышенным содержанием урана [Kraynov et al., 2012].

Действительно, в пределах участков «Мухоршибирь» и «Улан-Удэ» основная часть водопроявлений принадлежит к группе II, причем три источника являются радоновыми (рис. 4, $A$ ). На остальных участках воды также относятся к двум группам, но за единственным исключением (участок «Подкаменная») - это группы I и II. К той же совокупности следует отнести и забайкальский участок «Татаурово», что смещает границу распространения радоновых вод на юго-восток от активных структур центральной части Байкальского рифта. На рассматриваемой территории она приурочена к Джида-Удинскому глубинному разлому, в юго-восточном крыле которого вследствие процессов мезозойской тектономагматической активизации получили широкое распространение разнотипные магматические комплексы. Характерно, что в этом месте проходит граница между Байкальской провинцией азотных и метановых терм и Забайкальской провинцией холодных углекислых вод (см. рис. 3, $A)$. Таким образом, определяющая роль вещественного фактора для формирования геохимического состава подземных вод в данном случае распространяется и на содержание радиоактивного газа.

Существование в каждой из гидроминеральных провинций двух групп подземных вод, отличающихся содержанием радона, объясняется наличием разломов, как это, в частности, было показано на примере Тункинского сброса (см. рис. 3). В субстрате разломных зон вследствие геодинамической активности и повышенной проницаемости усиливается выход радона. Газ, растворяясь в циркулирующей воде, повышает ее радиоактивность над фо- ном, характерным для породного массива. Так, материалы по трансекту Баяндай - Мухоршибирь наглядно показывают (рис. 4, A), что в ВосточноСибирской и Байкальской провинциях общий фон радиоактивности отражают водопроявления из группы I, а аномальными являются источники из группы II, приуроченные к структурам разломного происхождения (Прибайкальская флексура, Приморский и Бортовой разломы). В Забайкальской провинции подземные воды группы II еще относятся к фоновым, а аномалии, связанные с ДжидаУдинским и Тугнуй-Кондинским разломами, представлены источниками собственно радоновых вод. Немногочисленные источники группы III представляют аномалии, однако в Байкальской и Забайкальской провинциях, судя по данным [Mineral waters..., 1962], они связаны, соответственно, с высоко- и низкорадиоактивными породами.

Таким образом, пространственные вариации радиоактивности подземных вод Прибайкалья и Забайкалья определяются вещественным и структурным факторами. Радиоактивность пород обусловливает главным образом фоновое содержание радона в подземных водах изучаемой площади. Присутствие активного разлома, как правило, создает аномальную концентрацию радона в дренирующем его водоисточнике, который в этом случае будет относиться к более высокой группе по радиоактивности.

\section{3. ЗАКОНОМЕРНОСТИ ВРЕМЕННЫХ ВАРИАЦИЙ СОДЕРЖАНИЯ РАДОНА В ПОДЗЕМНЫХ ВОДАХ ПРИБАЙКАЛЬЯ И ЗАБАЙКАЛЬЯ}

Использование классификации подземных вод Прибайкалья и Забайкалья по содержанию радона, а также применение представленных выше пространственных закономерностей их распределения осложняются вариациями параметра $Q$ во времени. На сегодняшний день существует множество работ, посвященных анализу данных эманационного мониторинга подземных вод. Они, в частности, свидетельствуют, что содержание радона в одном водоисточнике с течением времени может меняться в несколько раз. В основном мониторинговые исследования проводятся в связи с поиском предвестников сильных землетрясений [Toutain, Baubron, 1999; Ghosh et al., 2009; Woith, 2015]. Они актуальны и для территории Прибайкалья, характеризующейся сложным тектоническим строением и интенсивной сейсмичностью в связи с развитием Байкальского рифта. В рассматриваемом регионе исследования прогностической направленности, базирующиеся на мониторинге содержания радона в подземных водах, начаты сравнительно недавно [Seminsky, Tugarina, 2013; Lopatin, 2015]. Однако до сих пор 


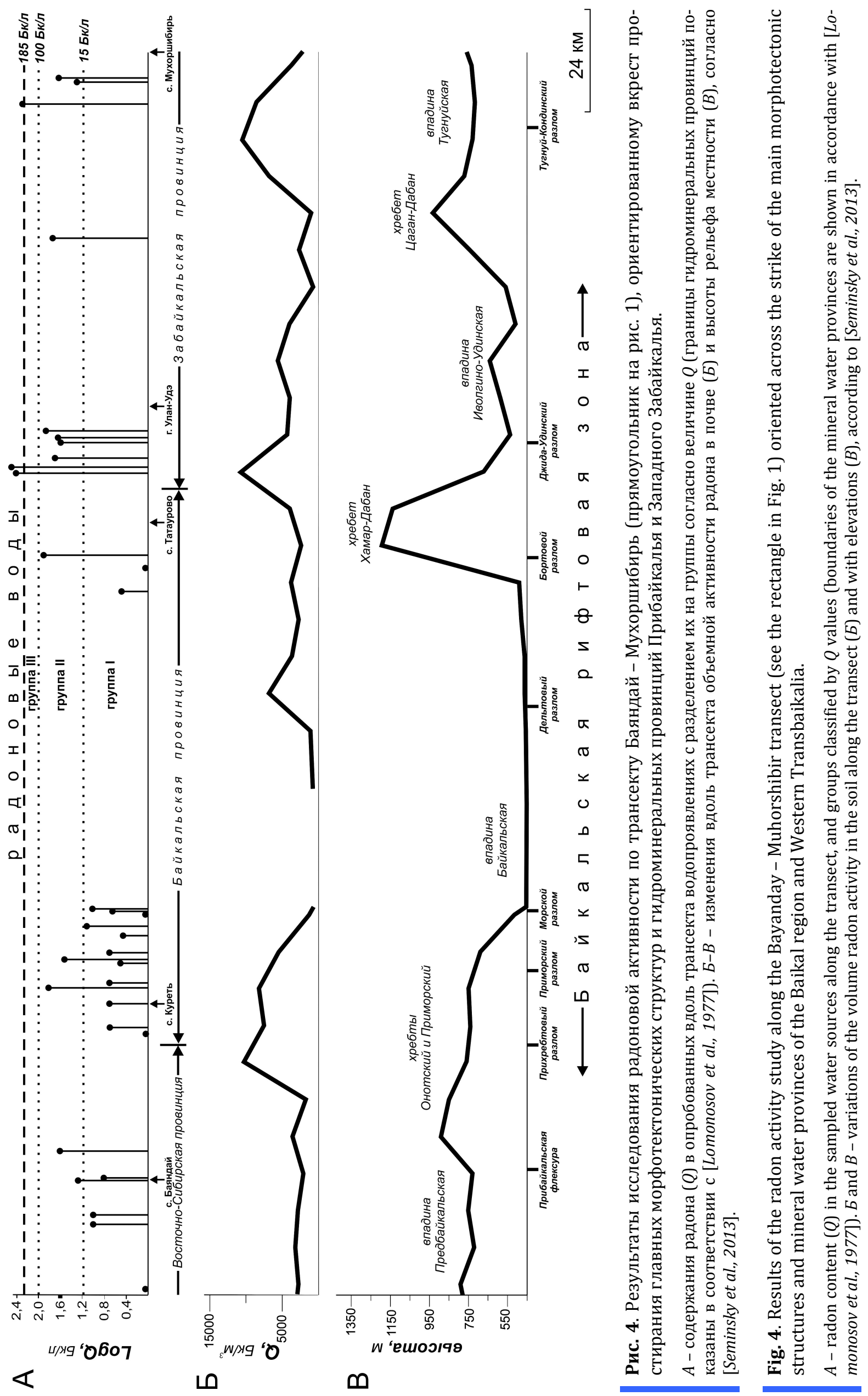




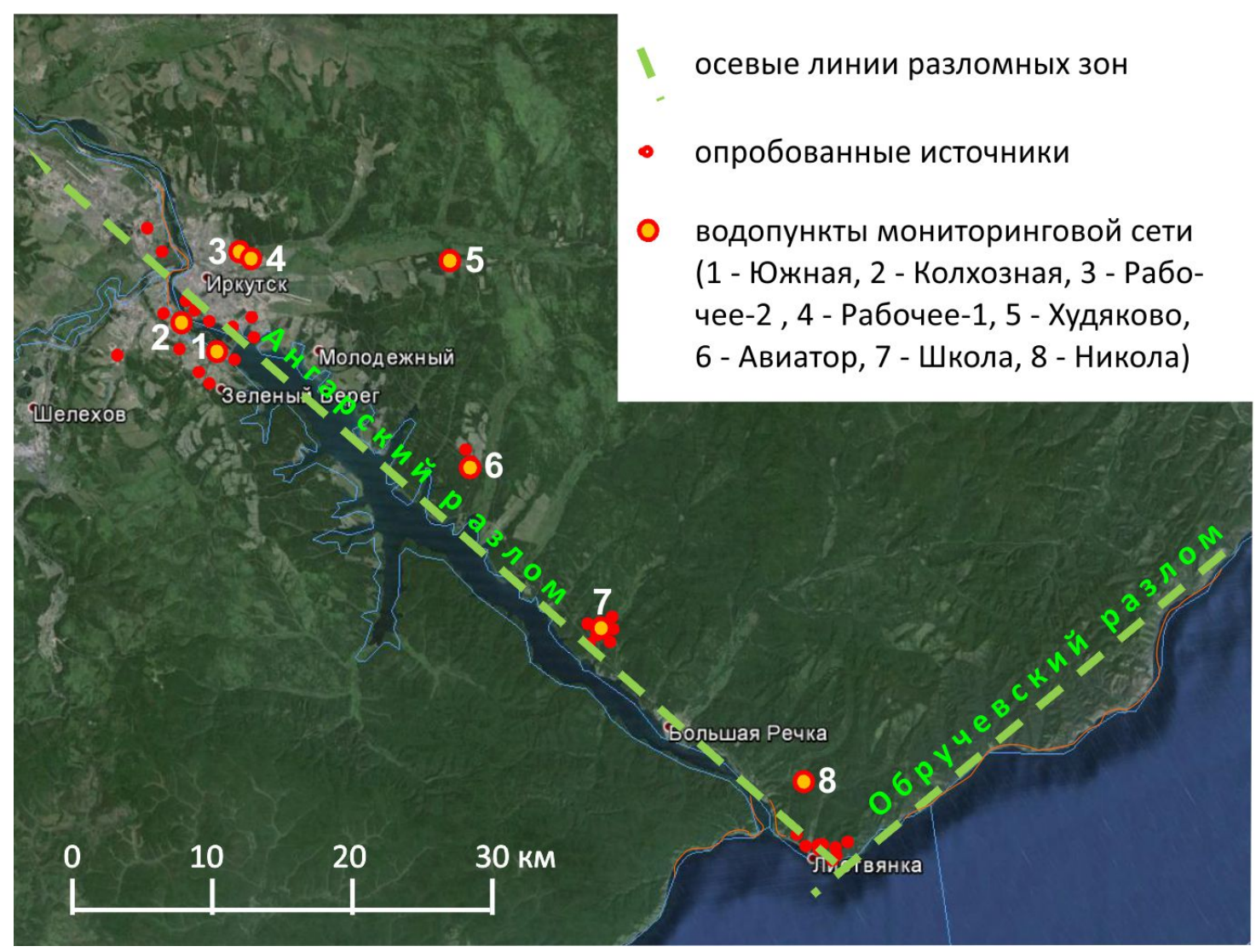

Рис. 5. Схема опробованных водопроявлений на территории Южного Приангарья.

Fig. 5. Scheme showing sampled water sources in Southern Priangarie.

практически не изучены общие закономерности временных вариаций параметра $Q$ и не выявлены главные факторы, их определяющие.

В рамках данного исследования мониторинговые измерения проводились на селитебной территории Южного Приангарья (см. рис. 1), где подземные воды используются для хозяйственно-питьевого водоснабжения. Кроме того, регион принадлежит к зоне влияния крупного Ангарского разлома на отрезке Листвянка - Иркутск, непосредственно связанном с сетью разрывов сейсмоактивного Байкальского рифта. Судя по полученным ранее данным [Seminskii et al., 2001], Ангарский разлом не имеет единого магистрального сместителя, а представлен широкой полосой сгущения локальных разрывов северо-западного (до субмеридионального) простирания, взаимодействующих с нарушениями северо-восточной (до субширотной) ориентировки. На современном этапе тектогенеза разломная зона характеризуется неравномерной активностью: высокой - в границах Байкальского рифта и низкой - в окрестностях г. Иркутска. Это позволило выбрать для эманационного мониторинга водопункты, относящиеся к разным группам по содержанию радона.
Согласно предложенной классификации (табл. 1), несколько десятков водопроявлений, опробованных в Южном Приангарье (рис. 5), относятся по радиоактивности к двум первым группам. Из водопунктов группы I эманационный мониторинг осуществлялся в точках № 2, 6 и 7. Из водопроявлений группы II для проведения постоянных измерений было выбрано пять пунктов, причем они представляли каждый из двух максимумов, выделяющихся на гистограмме (см. рис. 2) в поле значений $16 \leq Q \leq 99$ Бк/л и, таким образом, представляющих подгруппы ( $\mathrm{II}_{1}$ и $\left.\mathrm{II}_{2}\right)$. К первой из них относятся пункты мониторинга № 1, 3 и 4, а ко второй - 5 и 8. Во всех водопунктах измерения проводились с частотой один раз в две недели при периоде наблюдений более девяти месяцев и максимальном непрерывном ряде измерений более 2.5 лет (водопункты № 1, 3 и 4).

Результаты мониторинговых измерений для восьми выбранных водопроявлений представлены на рис. $6, A$, и в табл. 2 .

Анализ вариаций параметра $Q$ по абсолютной величине свидетельствует, что предложенная классификация подземных вод (см. табл. 1) может быть успешно использована на изученной территории. 

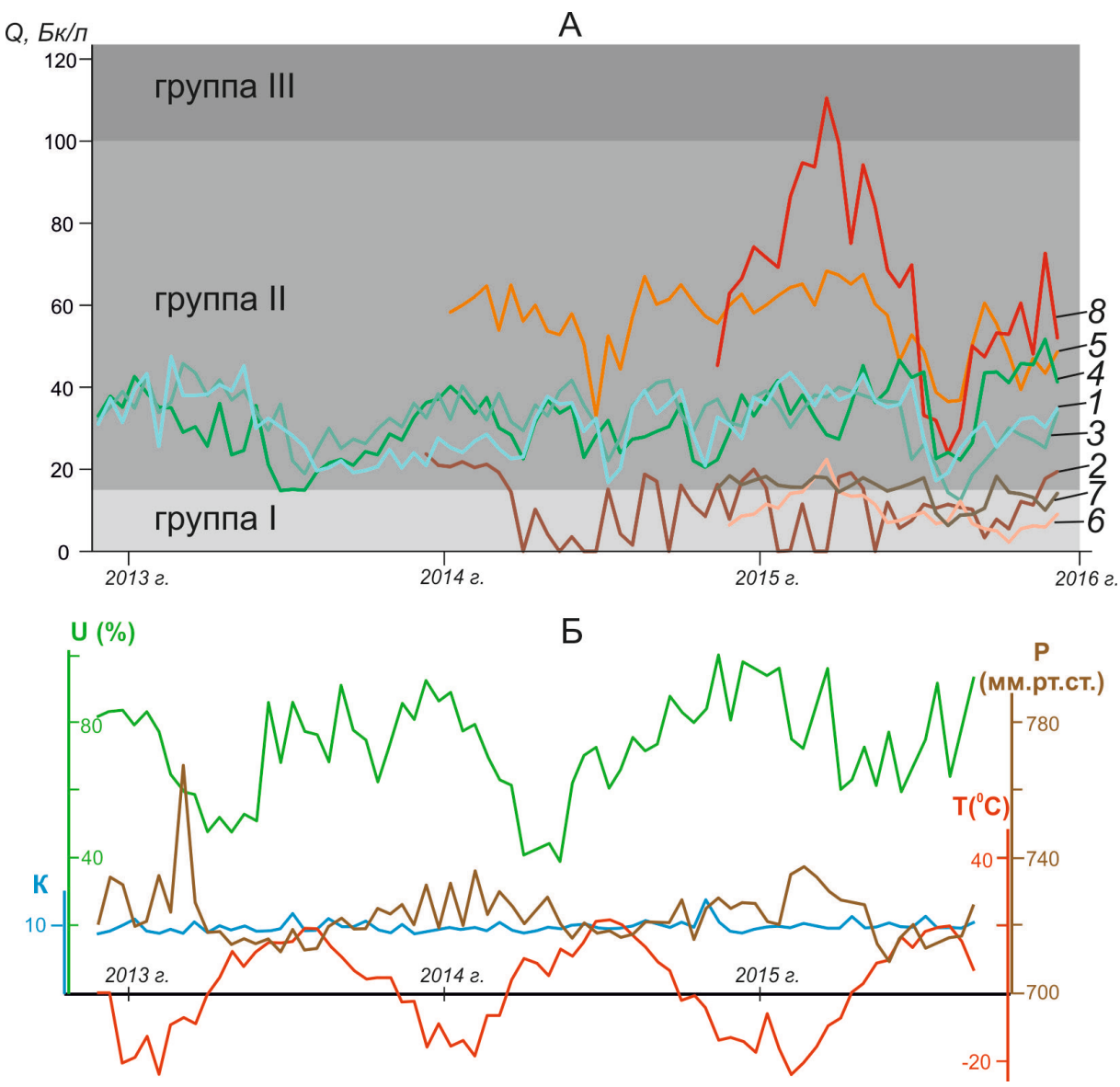

Рис. 6. Результаты мониторинга содержания радона $(Q)$ в восьми водопроявлениях Южного Приангарья $(A)$ в сравнении с вариациями атмосферного давления (P), температуры (T) и влажности воздуха (U), а также энергетическим классом наиболее сильного землетрясения (K), произошедшего в день опробования на территории Байкальского рифта (Б).

На рис. $A$ цифрами справа отмечены кривые для разных водопунктов (1 - Южная, 2 - Колхозная, 3 - Рабочее-2, 4 - Рабочее-1, 5 Худяково, 6 - Авиатор, 7 - Школа, 8 - Никола), а разными оттенками серого цвета - области величин $Q$, соответствующих подземным водам из трех разных групп по содержанию радона.

Fig. 6. Results of radon content $(Q)$ monitoring in eight water sources in Southern Priangarie $(A)$ versus variations in atmospheric pressure (P), air temperature (T) and relative humidity (U), as well as the energy class of the strongest earthquake $(\mathrm{K})$ that occurred on the day of sampling in the Baikal rift $(\bar{b})$.

In Figure A, numbers on the right correspond to the numbers of curves for different water facilities (1 - Yuzhnaya, 2 - Kolkhoznaya, 3 Rabocheye-2, 4 - Rabocheye-1, 5 - Khudyakovo, 6 - Aviator, 7 - School, 8 - Nikola). Fields that differ in $Q$ values, corresponding to groundwaters from three different radon-content groups, are shown by different shades of the grey colour.

Т а б л и ц а 2. Средние $\left(Q_{c p}\right)$, максимальные $\left(Q_{\text {макс }}\right)$ и минимальные $\left(Q_{\text {мин }}\right)$ содержания радона, полученные для каждого из пунктов эманационного мониторинга в Южном Приангарье

T a b l e 2. Mean $\left(Q_{c p}\right)$, maximum $\left(Q_{\text {макс }}\right)$ and minimum $\left(Q_{\text {мин }}\right)$ contents of radon for each of the emanation monitoring points in Southern Priangarie

\begin{tabular}{llllll}
\hline Группы водопунктов & Номера водопунктов & $Q_{c p}$ Бк/л & $Q_{\text {макс, Бк/л }}$ & $Q_{\text {мин, Бк/л }}$ & $Q_{\text {макс }}-Q_{\text {мин, Бк/л }}$ \\
\hline I & 2 & 10.7 & 23.7 & 0 & 23.7 \\
& 6 & 9.7 & 22.4 & 2.2 & 20.2 \\
II $_{1}$ & 7 & 14.7 & 18.4 & 6.3 & 12.1 \\
& 1 & 31.2 & 47.5 & 16.8 & 30.7 \\
II $_{2}$ & 3 & 32.7 & 45.8 & 12.4 & 33.4 \\
& 4 & 31.8 & 51.7 & 14.8 & 36.9 \\
\end{tabular}


Изменения параметра $Q$ происходят главным образом в пределах значений, соответствующих определенной группе, и случайное измерение в большинстве случаев позволит верно классифицировать изучаемое водопроявление. В большей мере это касается источников из второй группы и в меньшей степени - водопроявлений из группы I.

Как предполагалось ранее, источники из первой группы на данной территории по содержанию радона относятся к фоновым. Они получают питание за счет атмосферных осадков и поверхностного стока и практически не имеют связи с обогащенными радоном более глубокими водами. В отдельные моменты времени радиоактивность подобных вод падает до нуля вследствие разбавления атмосферными осадками или для территории г. Иркутска - техногенными водами (рис. $6, A$ ). Исключением является водопроявление № 7, которое отличается высоким $Q_{c p}$ и нередко показывает значения, соответствующие группе II. Расположение источника в прямолинейной долине (см. рис. $5, A$ ) предполагает его связь с разрывом. Однако это мелкий разлом в пределах слабоактивного сегмента зоны Ангарского разлома, что не позволяет водопроявлению № 7 занять устойчивую позицию в группе II.

Источники из группы II относятся к аномальным и формируются за счет подземных вод, приуроченных к разломам (рис. $6, A$ ). Это, с одной стороны, существенно ограничивает их разбавление поверхностными водами, а с другой - обеспечивает определенным уровнем концентрации радона, соответствующим конкретной структурно-вещественной обстановке. Так, заметное различие уровней радиоактивности у источников данной группы $\left(\mathrm{II}_{1} \quad \mathrm{II}_{2}\right)$ может быть связано с их приуроченностью к тектоническим нарушениям, представляющим зону Ангарского разлома в его менее активной северо-западной части (№ $1,3,4)$ и более активной - юго-восточной (№ 8) (см. рис. 5). Данной закономерности не подчиняется источник № 5 , но удаленность на 15 км от оси Ангарского разлома позволяет усомниться в его принадлежности к изучаемой разломной зоне.

Периодический выход значений $Q$ в водоисточнике за пределы величин, соответствующих определенной группе, обусловлен существенными вариациями параметра $Q$ во времени (рис. 6, $A$ ). Разброс его значений в одном водопроявлении из первой группы составляет 0-23.7 Бк/л, а из группы II 24.0-110.5 Бк/л (табл. 2). Как следствие, водопункты из группы I зачастую показывают содержания радона, соответствующие группе II. В источниках из подгруппы II $_{1}$ радиоактивность иногда понижается до значений, характерных для группы I. В роднике № 8 из подгруппы $\mathrm{II}_{2}$, отличающемся наибольшей вариабельностью в содержании радо- на, были получены наиболее высокие значения $Q$, соответствующие третьей группе подземных вод, согласно принятой классификации.

Анализ характера вариаций параметра $Q$ свидетельствует о колебаниях радиоактивности подземных вод, которые могут определяться влиянием внутренних (геодинамических) или внешних (атмосферных) по отношению к Земле факторов. Согласно опыту исследований в других регионах [Toutain, Baubron, 1999; Zmazek et al., 2000; Prasad et al., 2009; Smetanova et al., 2010; Nevinsky et al., 2015], в качестве показателей первых их них мы использовали атмосферное давление (Р), температуру (Т) и влажность (U) воздуха [Weather forecast..., 2016]. Количественной характеристикой воздействия внутренних факторов в данном случае являлся энергетический класс наиболее сильного землетрясения (К), произошедшего в день опробования на территории Байкальского рифта [Baikal Branch..., 2016]. Вариации этих параметров в течение периода мониторинга представлены на рис. 6 , 5 , а теснота степени связи с содержанием радона в каждом из водопунктов - в табл. 3 .

Судя по коэффициентам парных корреляций (табл. 3), зависимость величины $Q$ от параметров К и U отсутствует. На уровне тенденций для большинства пунктов мониторинга имеет место связь содержания радона с величинами температуры воздуха и атмосферного давления, причем в первом случае она обратная, а во втором - прямая. Для параметра Р подобные зависимости были установлены при анализе результатов мониторинга радона на Кавказе [Nevinsky et al., 2015], а для параметра $\mathrm{T}$ - в Венгрии [Smetanova et al., 2010] и Турции [Erdogan et al., 2013]. Особенностью наших наблюдений является закономерная тенденция к увеличению коэффициентов корреляции рассматриваемых зависимостей для источников с бо́льшим содержанием радона. Так, для водопроявлений из группы $\mathrm{II}_{2}$ существование связи параметра $Q$ с величинами Т и Р можно считать твердо установленным.

Отрицательный результат коррелирования параметров $Q$ и К для региона, частично относящегося к сейсмоактивному Байкальскому рифту, не свидетельствует об отсутствии влияния внутренних факторов на содержание радона в подземных водах рассматриваемой территории. Причиной полученного результата, по-видимому, является сравнительно низкая сейсмическая активность в регионе в течение периода мониторинга. В частности, отсутствовали сильные землетрясения, с которыми связаны значимые изменения напряженного состояния породного массива. Подобные вариации отражаются на содержании радона в подземных водах сейсмоактивных регионов мира [Toutain, 
Т а б л и ц а 3. Коэффициенты корреляции, рассчитанные для зависимостей содержания радона в пунктах мониторинга от температуры воздуха (T), атмосферного давления (P), влажности воздуха (U) и энергетического класса наиболее сильного землетрясения (K), произошедшего в день опробования на территории Байкальского рифта

$\mathrm{T}$ a b l e 3. Correlation coefficients calculated for monitoring stations with respect to the relationships between radon contents and air temperature $(T)$, atmospheric pressure $(P)$, relative air humidity (U) and the energy class of the strongest earthquake $(K)$ that occurred on the day of sampling in the Baikal rift

\begin{tabular}{llllll}
\hline Группы водопунктов & Номера водопунктов & $\mathrm{K}$ & $\mathrm{T}$ & $\mathrm{P}$ & $\mathrm{U}$ \\
\hline $\mathrm{I}$ & 2 & -0.17 & 0.13 & -0.11 & 0.24 \\
& 6 & 0.10 & -0.35 & 0.52 & 0.19 \\
$\mathrm{II}_{1}$ & 7 & -0.13 & -0.44 & 0.39 & 0.30 \\
& 1 & -0.01 & -0.52 & 0.58 & 0.01 \\
$\mathrm{II}_{2}$ & 3 & -0.06 & -0.42 & 0.54 & -0.05 \\
& 4 & 0.19 & -0.15 & 0.03 & 0.12 \\
& 5 & -0.24 & -0.71 & 0.83 & -0.05 \\
\hline
\end{tabular}

Baubron, 1999; Ghosh et al., 2009; Woith, 2015] и, следовательно, в каком-то виде должны проявляться для источников Южного Приангарья. Перспективы исследований в данном направлении связаны с продолжением мониторинга, а также с использованием в корреляции с $Q$ комплекса параметров, более полно отражающих сейсмическую активность и криповые деформации в зонах обводненных разломов.

Интерпретация результатов корреляции содержания радона с метеопараметрами (U, P и T) основывается на сезонных изменениях погоды в Прибайкалье. Они отчетливо проявлены на рис. 6,5 , в закономерно связанных между собой колебаниях рассматриваемых параметров. Максимальные значения для температуры воздуха имеют место летом, а для величины атмосферного давления и влажности воздуха - зимой. Синхронность сезонных изменений метеопараметров в меньшей степени свойственна влажности воздуха и отчетливо проявлена для вариаций температуры и давления, которые происходят в противофазе. Эти два параметра, как правило, имеют отчетливую взаимосвязь с величиной $Q$, причем полученные в ходе анализа коэффициенты корреляции характеризуются близкими значениями для отдельно рассматриваемого водопроявления (табл. 3). Следовательно, сезонные вариации содержания растворенного газа в подземных водах Южного Прибайкалья определяются именно температурой и давлением.

В метеорологическом отношении ведущая роль в установленных соотношениях принадлежит температуре воздуха, сезонное влияние которой на содержание радона в водоисточниках осуществляется опосредованно и для климатических условий Прибайкалья может быть вызвано тремя основными причинами. Во-первых, падение значений Т может приводить к снижению температуры воды в источниках подземных вод, а значит, - к повышению растворимости радона, так как два последних параметра связаны обратной зависимостью [Erdogan et al., 2013; Schubert et al., 2012]. Во-вторых, зимой в период низких температур в Прибайкалье не происходит снижения концентрации радона в подземных водах за счет их разбавления атмосферными осадками, что имеет место в летнее время. Косвенным признаком влияния данного фактора является известная тенденция повышения дебита летом и снижения в зимний период у естественных водопроявлений. В-третьих, характерное для юга Восточной Сибири зимнее промерзание верхнего слоя грунтов практически повсеместно препятствует свободному выходу радона. Это приводит к его вынужденному накоплению и росту концентрации в подземных водах, которые транспортируют радиоактивный газ к поверхности по разломам. Важное свидетельство влияния описываемого сезонного фактора на концентрацию радона - смещение максимумов величины $Q$ к началу весны (концу меженного периода), когда, несмотря на повышение температуры воздуха, глубина промерзания почвы является наибольшей (рис. 6). Разная степень выраженности данного эффекта у различных кривых может быть связана, во-первых, со спецификой промерзания грунтов в локальной обстановке и, во-вторых, с характером конкретного водопроявления.

Именно второй фактор может быть причиной более тесных связей величины $Q$ с температурой и давлением для приуроченных к разломам глубоких вод (группа II), несмотря на, казалось бы, большую подверженность атмосферному влиянию близповерхностных водопроявлений (группа I) (табл. 3). Данная закономерность объясняется разным воздействием атмосферной нагрузки на близповерх- 
ностные поровые коллекторы грунтовых вод и трещинные коллекторы глубоких трещинно-жильных вод. В первом случае радон беспрепятственно растворяется в воде и вариации параметра Р практически не меняют его концентрацию. Во втором случае часть газа находится в полостях трещин и повышение атмосферного давления «выжимает» его в подземные воды, которые переносят радон по разломам к поверхности. Таким образом, вариации величины Р более заметно влияют на радиоактивность подземных вод из источников второй группы и в меньшей степени - близповерхностных водопроявлений из группы I.

Следует отметить, что атмосферное давление является одним из ключевых параметров, контролирующих концентрацию радона в почвенном воздухе [Schery et al., 1982; Rudakov, 1985; Zmazek et al., 2003; Spivak, 2010; Seminsky, Bobrov, 2013; Adushkin, Spivak, 2014]. Однако связь между объемной активностью почвенного радона и величиной Р, установленная для Прибайкалья, противоположна той, которая представлена в данной статье для содержания радона в подземных водах. В годичном цикле, а также при колебаниях с периодом 4 сут повышение атмосферного давления препятствует, а уменьшение, наоборот, способствует выходу радона из почвы в атмосферу. Следовательно, среда, в которой находится радиоактивный газ, играет принципиальную роль во взаимоотношениях эманаций с внешними факторами.

Итак, вариации параметра $Q$ в водоисточниках Южного Приангарья имеют колебательный характер и происходят под действием главным образом внешних факторов, в проявлении которых основную роль играет изменение температуры воздуха. Сезонный тренд для радиоактивности подземных вод проявляется в повышении содержания радона зимой и его понижении в летний период. Он хорошо выражен у глубоких приразломных источников из группы II и менее отчетливо - у близповерхностных водопроявлений, что связано с различием условий их формирования.

\section{3. ЗАКЛЮЧЕНИЕ}

Результаты анализа концентрации радона $(Q)$ в десятках водопроявлений Прибайкалья и Забайкалья, а также многомесячных мониторинговых измерений параметра $Q$ в восьми источниках Южного Приангарья позволили установить наиболее общие закономерности и факторы пространственной и временной изменчивости содержания ${ }^{222} \mathrm{Rn}$ в подземных водах изучаемого региона.

Воды Прибайкалья и Забайкалья классифицируются по содержанию радона на семь основных групп. Граничные значения параметра $Q$ для трех первых групп с относительно низким содержанием радона были установлены на основе статистического анализа собственной базы данных: группа I $Q \leq 15$ Бк/л, группа II - $16 \leq Q \leq 99$ Бк/л, группа III $100 \leq Q \leq 184$ Бк/л. Для остальных групп водопроявлений, представляющих собственно радоновые воды (см. IV-VII в табл. 1), приняты уровни параметра $Q$ из уже используемой в России классификации [Kulikov et al., 1991], так как они не противоречат немногочисленным оценкам, полученным в пределах изученного региона. В подавляющем большинстве водопроявлений концентрация радона не превышает объективно существующего предела 100 Бк/л, который, таким образом, целесообразен для применения в качестве уровня вмешательства при подготовке питьевых вод для городов и поселений Прибайкалья и Забайкалья.

Закономерности пространственного распределения водопроявлений, относящихся к разным группам по содержанию радона, в изученном регионе определяются вещественным и структурным факторами. Радиоактивность пород обусловливает фоновое содержание радона в подземных водах, которое к северо-западу от Джида-Удинского глубинного разлома (в Прибайкалье) соответствует группе I, а к юго-востоку - группе II вследствие широкого распространения на территории Забайкалья магматитов с повышенным содержанием урана. Присутствие активного разлома земной коры, как правило, создает аномальную концентрацию радона в дренирующем его водоисточнике, который в этом случае будет относиться к более высокой группе по радиоактивности: для Прибайкалья - это группа II, а для Забайкалья - группы III-VI. Радиоактивность подземных вод меняется вкрест и вдоль простирания разлома ввиду неоднородности его внутреннего строения и неравномерной активности на современном этапе тектогенеза. Как следствие, перспективы поиска на активно осваиваемом юго-западном побережье оз. Байкал подземных вод группы III, пригодных для использования в санаторной практике, связаны с разбуриванием обводненных разломов, поскольку концентрация радона в поверхностных источниках данной территории, как правило, не превышает 100 Бк/л.

Общие закономерности временной изменчивости содержания радона в подземных водах Прибайкалья, согласно результатам мониторинга водопроявлений в зоне влияния крупного Ангарского разлома, определяются внешними факторами. К главным из них относятся промерзание верхнего слоя грунтов зимой, разбавление подземных вод атмосферными осадками летом и периодические вариации давления, которые тесно связаны с закономерным изменением температуры воздуха. 
Перечисленные факторы по-разному влияют на источники с разным средним содержанием радона, но общая тенденция заключается в наличии сезонных колебаний радиоактивности подземных вод с наиболее высокими значениями $Q$ зимой и сравнительно низкими - летом. Для близповерхностных водопроявлений из группы I содержание радона может меняться на единицы и первые десятки, а для глубоких приразломных водопроявлений группы II - на многие десятки беккерелей на литр. Как следствие, в непродолжительные периоды проявления экстремальных значений $Q$ содержание радона в воде конкретного водоисточника может повыситься или понизиться до значений, соответствующих смежной группе по радиоактивности.

Закономерности временных вариаций радиоактивности подземных вод Южного Приангарья были установлены в ходе мониторинговых измерений, осуществляемых один раз в полмесяца. Подобная частота опробования и отсутствие в Байкальском рифте сильных землетрясений за период мониторинга не позволили установить значимой взаимосвязи между содержанием радона в водопроявлениях и сейсмической активностью. Однако проведенное исследование подготовило основу для целенаправленных работ по поиску эманационных предвестников землетрясений в Прибайкалье. В частности, установлено, что измерения содержания радона необходимо осуществлять ежедневно в сети источников, подобных водопункту «Никола» (см. рис. $5,6, A)$. Он принадлежит к приразломным водопроявлениям из группы II и характеризуется отчетливым сезонным трендом изменений параметpa $Q$, который легко учесть при выявлении предвестниковых сигналов.

Таким образом, в работе охарактеризована радоновая активность подземных вод обширного региона, причем особый акцент сделан на закономерностях пространственной и временной изменчивости содержания ${ }^{222 \mathrm{Rn}}$ в водопроявлениях с $Q<185$ Бк/л. Они наиболее распространены в Прибайкалье и, несмотря на низкое содержание радона, являются важным объектом дальнейших целенаправленных исследований при решении вопросов сейсмобезопасности, питьевого водоснабжения и поиска лечебных вод в рассматриваемом регионе активного природопользования.

\section{4. БЛАГОДАРНОСТИ}

Авторы благодарны профессору, доктору физ.мат. наук А.А. Спиваку и кандидату геол.-мин. наук C.X. Павлову за ценные советы и рекомендации, высказанные в ходе подготовки материалов к публикации. Исследования проводились в рамках интеграционной программы ИНЦ СО РАН «Фундаментальные исследования и прорывные технологии как основа опережающего развития Байкальского региона и его межрегиональных связей (03412015-0001)».

\section{5. ЛИТЕРАTУРА / REFERENCES}

Adushkin V.V., Spivak A.A., 2014. Physical Fields in the Near-Surface Geophysics. GEOS, Moscow, 360 p. (in Russian) [Адушкин B.B., Спивак А.А. Физические поля в приповерхностной геофизике. М.: ГЕОС, 2014. 360 с.].

Baikal Branch of the Geophysical Survey. The main catalogue of events. Available from: http://seis-bykl.ru (last accessed February 10, 2016) (in Russian) [Байкальский филиал геофизической службы. Основной каталог событий. Режим доступа: http://seis-bykl.ru (дата обращения: 10.02.2016)].

Chernyago B.P., Nepomnyashchikh A.I., Medvedev V.I., 2012. Current radiation environment in the central ecological zone of the Baikal Natural Territory. Russian Geology and Geophysics 53 (9), 926-935. http://dx.doi.org/10.1016/ j.rgg.2012.07.008.

Erdogan M., Eren N., Demirel S., Zedef V., 2013. Determination of radon concentration levels in wellwater in Konya, Turkey. Radiation protection dosimetry 156 (4), 489-494. http://dx.doi.org/10.1093/rpd/nct099.

Express Method for Measurement of ${ }^{222}$ Rn Volume Activity in Soil Air by PPA Radon Radiometers. Recommendation, 2004. Doza NPP, Moscow, 16 p. (in Russian) [Методика экспрессного измерения объемной активности ${ }^{222} \mathrm{Rn}$ в почвенном воздухе с помощью радиометра радона типа РРА. Рекомендация. М.: НПП «Доза», 2004. 16 с.]

Ghosh D., Deb A., Sengupta R., 2009. Anomalous radon emission as precursor of earthquake. Journal of Applied Geophysics 69 (2), 67-81. http://dx.doi.org/10.1016/j.jappgeo.2009.06.001.

Guerra M., Etiope G., 1999. Effects of gas-water partitioning, stripping and channelling processes on radon and helium gas distribution in fault areas. Geochemical Journal 33 (3), 141-151. http://doi.org/10.2343/geochemj.33.141.

Koval P.V., Udodov Y.N., San'kov V.A., Yasenovskii A.A., Andrulaitis L.D., 2006. Geochemical activity of faults in the Baikal Rift Zone (mercury, radon, and thoron). Doklady Earth Sciences 409 (2), 912-915. http://dx.doi.org/10.1134/ S1028334X06060171.

Kraynov S.R., Rizhenko B.N., Shvets V.M., 2012. Geochemistry of Groundwater. Theoretical, Applied and Environmental Aspects. CentrLitNefteGaz, Moscow, 672 p. (in Russian) [Крайнов С.Р., Рыженко Б.Н., Швец В.М. Геохимия подземных вод. Теоретические, прикладные и экологические аспекты. М.: ЦентрЛитНефтеГаз, 2012. 672 с.]. 
Kulikov G.V., Zhelvakov A.V., Bondarenko S.S., 1991. Mineral Medicinal Waters of the USSR: A Handbook. Nedra, Moscow, 399 p. (in Russian) [Куликов Г.В., Желваков А.В., Бондаренко С.С. Минеральные лечебные воды СССР: Справочник. М.: Недра, 1991. 399 с.].

Lomonosov I.S., Kustov Yu.I., Pinneker E.V., 1977. Mineral Waters of the Pribaikalie. East Siberian Publishing House, Irkutsk, 224 p. (in Russian) [Ломоносов И.С., Кустов Ю.И., Пиннекер Е.В. Минеральные воды Прибайкалья. Иркутск: Вост.-Сиб кн. изд-во, 1977. 224 с.].

Lopatin M.N., 2015. Variations of dissolved radon concentrations in groundwater of the Southern Pribaikalie during earthquake preparation and occurrence. In: Lithosphere structure and geodynamics. Institute of the Earth's Crust SB RAS, Irkutsk, p. 108-109 (in Russian) [Лопатин М.H. Вариации концентраций растворенного радона в подземных водах Южного Прибайкалья при подготовке и реализации очагов землетрясений // Строение литосферы и геодинамика. Иркутск: ИЗК СО РАН, 2015. С. 108-109].

Mineral waters of the southern regions of East Siberia, vol. II. 1962. Publishing House of the USSR Academy of Sciences, Moscow, St. Petersburg, 200 p. (in Russian) [Минеральные воды южной части Восточной Сибири. Т. II. М.-Л.: Изд-во АН СССР, 1962. 200 с.].

Myasnikov A.A., Samovich D.A., Kokarev A.A., Gavrilov L.P., 2009. Uranium-bearing and radiation-ecological conditions of the southern regions of East Siberia. In: Radioactivity and radioactive elements in human environment. STT, Tomsk, p. 398-403 (in Russian) [Мясников А.А., Самович Д.А., Кокарев А.А., Гаврилов Л.П. Ураноносность и радиационно-экологическая обстановка территории юга Восточной Сибири // Радиоактивность и радиоактивные элементы в среде обитания человека. Томск: STT, 2009. С. 398-403].

Nevinsky I., Tsvetkova T., Nevinskaya E., 2015. Measurement of radon in ground waters of the Western Caucasus for seismological application. Journal of Environmental Radioactivity 149, 19-35. http://dx.doi.org/10.1016/j.jenvrad. 2015.07.005.

Plyusnin A.M., Astakhov N.E., Peryazeva E.G., 2009. Radon in surface and ground waters of Transbaikalia: conditions and regularities of dissolution. In: Radioactivity and radioactive elements in human environment. STT, Tomsk, p. 444-448 (in Russian) [Плюснин А.М., Астахов Н.Е., Перязева Е.Г. Радон в поверхностных и подземных водах Забайкалья: условия и закономерности растворения // Радиоактивность и радиоактивные элементы в среде обитания человека. Томск: STT, 2009. С. 444-448].

Prasad Y., Prasad G., Gusain G.S., Choubey V.M., Ramola R.C., 2009. Seasonal variation on radon emission from soil and water. Indian Journal of Physics 83 (7), 1001-1010. http://dx.doi.org/10.1007/s12648-009-0060-9.

Przylibski T.A., 2011. Shallow circulation groundwater - the main type of water containing hazardous radon concentration. Natural Hazards and Earth System Sciences 11 (6), 1695-1703. http://dx.doi.org/10.5194/nhess-11-1695 2011.

Rudakov V.P., 1985. About barometric variations of subsoil radon. Geokhimiya (Geochemistry) (1), 124-127 (in Russian) [Рудаков В.П. О барических вариациях подпочвенного радона // Геохимия. 1985. № 1. С. 124-127].

Schery S.D., Gaeddert D.H., Wilkening M.H., 1982. Transport of radon from fractured rock. Journal of Geophysical Research 87 (B4), 2969-2976. http://dx.doi.org/10.1029/JB087iB04p02969.

Schubert M., Paschke A., Lieberman E., Burnett W.C., 2012. Air-Water partitioning of ${ }^{222} \mathrm{Rn}$ and its dependence on water temperature and salinity. Environmental Science \& Technology 46 (7), 3905-3911. http://dx.doi.org/10.1021/ es204680n.

Seminskii K.Zh., Gladkov A.S., Lunina O.V., 2001. Tectonophysics of the Angara fault zone (Southern Siberian platform). Geologiya i Geofizika (Russian Geology and Geophysics) 42 (8), 1252-1262.

Seminsky A.K., Tugarina M.A., 2013. Specific features of radon distribution in groundwater of the Baikal region. In: Geology, exploration and survey of mineral resources and geological research methods. Irkutsk State Technical University, Irkutsk, p. 133-137 (in Russian) [Семинский А.К., Тугарина М.А. Особенности распределения радона в подземных водах Байкальского региона // Геология, поиски и разведка полезных ископаемых и методы геологических исследований. Иркутск: ИрГТУ, 2013. С. 133-137].

Seminsky K.Zh., Bobrov A.A., 2012. Spatial and temporal variations of soil-radon activity in fault zones of the Pribaikalie (East Siberia, Russia). Chapter 1. In: Z. Li, C. Feng (Eds.), Handbook of radon: properties, applications and health. Nova Science Publishers, New York, p. 1-36.

Seminsky K.Z., Bobrov A.A., 2013. The first results of studies of temporary variations in soil radon activity of faults in Western Pribaikalie. Geodynamics \& Tectonophysics 4 (1), 1-12 (in Russian) [Семинский К.Ж., Бобров А.А. Первые результаты исследований временных вариаций эманационной активности разломов Западного Прибайкалья // Геодинамика и тектонофизика. 2013. Т. 4. № 1. C. 1-12]. http://dx.doi.org/10.5800/GT-2013-4-10088.

Seminsky K.Z., Kozhevnikov N.O., Cheremnykh A.V., Pospeeva E.V., Bobrov A.A., Olenchenko V.V., Tugarina M.A., Potapov V.V., Zaripov R.M., Cheremnykh A.S., 2013. Interblock zones in the crust of the southern regions of East Siberia: tectonophysical interpretation of geological and geophysical data. Geodynamics \& Tectonophysics 4 (3), 203-278 (in Russian) [Семинский К.Ж., Кожевников Н.О., Черемных А.В., Поспеева Е.В., Бобров А.А., Оленченко В.В., Тугарина M.A., Потапов B.В., Зарипов Р.М., Черемных А.C. Межблоковые зоны в земной коре юга Восточной Сибири: тектонофизическая интерпретация геолого-геофизических данных // Геодинамика и тектонофизика. 2013. T. 4. № 3. C. 203-278]. http://dx.doi.org/10.5800/GT-2013-4-3-0099. 
Smetanova I., Holy K., Mullerova M., Polaskova A., 2010. The effect of meteorological parameters on radon concentration in borehole air and water. Journal of Radioanalytical and Nuclear Chemistry 283 (1), 101-109. http:// dx.doi.org/10.1007/s10967-009-0128-1.

Spivak A.A., 2010. The specific features of geophysical fields in the fault zones. Izvestiya, Physics of the Solid Earth 46 (4), 327-338. http://dx.doi.org/10.1134/S1069351310040051.

Steinitz G., Vulkan U., Lang B., Gilat A., Zafrir H., 1992. Radon emanation along border faults of the rift in the Dead Sea area. Israel Journal of Earth-Sciences 41 (1), 9-20.

Toutain J.-P., Baubron J.-C., 1999. Gas geochemistry and seismotectonics: a review. Tectonophysics 304 (1-2), 1-27. http://dx.doi.org/10.1016/S0040-1951(98)00295-9.

Trofimov V.T. (Ed.), 2000. Ecological Functions of the Lithosphere. Moscow State University, Moscow, 432 p. (in Russian) [Экологические функции литосферы / Ред. В.Т. Трофимов. М.: МГУ, 2000. 432 с.]

Weather Forecast, 2016. Irkutsk Weather Archive. Available from: http://rp5.ru (last accessed: February 10, 2016) (in Russian) [Расписание погоды. Архив погоды в Иркутске. Режим доступа: http://rp5.ru (дата обращения: 10.02.2016)].

Woith H., 2015. Radon earthquake precursor: A short review. The European Physical Journal Special Topics 224 (4), 611-627. http://dx.doi.org/10.1140/epjst/e2015-02395-9.

Zmazek B., Todorovski L., Dzeroski S., Vaupotic J., Kobal I., 2003. Application of decision trees to the analysis of soil radon data for earthquake prediction. Applied Radiation and Isotopes 58 (6), 697-706. http://dx.doi.org/10.1016/ S0969-8043(03)00094-0.

Zmazek B., Vaupotic J., Zivcic M., Premru U., Kobal I., 2000. Radon monitoring for earthquake prediction in Slovenia. Fizika B (Zagreb) 9 (3), 111-118.

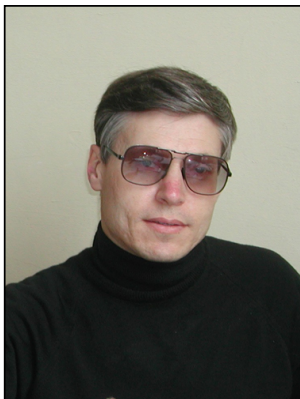

Семинский Константин Жанович, докт. геол.-мин. наук, зав. лабораторией тектонофизики

Институт земной коры СО РАН

664033, Иркутск, ул. Лермонтова, 128, Россия

Иркутский научный центр СО РАН

664033, Иркутск, ул. Лермонтова, 134, Россия

Тел.: 8(3952)423027; \ e-mail: seminsky@crust.irk.ru

Seminsky, Konstantin Zh., Doctor of Geology and Mineralogy, Head of Laboratory of Tectonophysics Institute of the Earth's Crust, Siberian Branch of RAS

128 Lermontov street, Irkutsk 664033, Russia

Irkutsk Scientific Center, Siberian Branch of RAS

134 Lermontov street, Irkutsk 664033, Russia

Tel.: 8(3952)423027; $₫$ e-mail: seminsky@crust.irk.ru

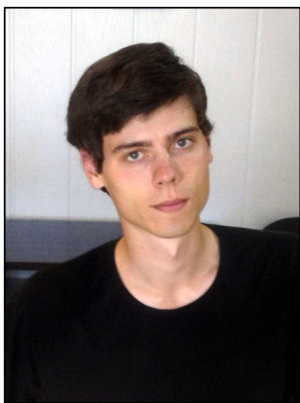

Семинский Александр Константинович, аспирант

Институт земной коры СО РАН

664033, Иркутск, ул. Лермонтова, 128, Россия

Seminsky Alexander K., postgraduate student Institute of the Earth's Crust, Siberian Branch of RAS

128 Lermontov street, Irkutsk 664033, Russia 